$$
\text { Járosi Márton - Kovács Pál }
$$

\title{
Az energiaunió és a tagállami felelösség
}

\section{Energy Union and Responsibility of Member Countries}

\section{Összefoglalás}

Az energiaellátás biztonságáért való felelôsség kérdése nem hagyható figyelmen kívül, amikor a központosított, egységes európai villamosenergia-piacról beszélünk. Az európai tagállamok ebben a piacegységesítési folyamatban eltérô induló pozíciókkal rendelkeznek. A kisebb országok, a kisebb méretú villamosenergia-piacok az energiakosaruk fontos elemeit veszíthetik el, éppen azokat, amelyek jelentôs mértékben járulnak hozzá az ellátásbiztonságukhoz. Ugyanakkor a folyamatosan növekvô áramimport, a tôlünk távol lévô és megbízhatatlan energiaforrásoktól való függôség eddig teljesen ismeretlen területeire vezeti Európát, mialatt az ellátás biztonságáért való felelôsség továbbra is tagállami hatáskör maradt. Ez a folyamat a piaci szereplók koncentrációjához vezethet, ami nyilvánvaló veszélyt jelent a kisebb piacok számára. Az áramellátás biztonságának sérülése egy bizonyos határon túl már elfogadhatatlan az Európai Unió néhány tagállama részére.

Journal of Economic Literature (JEL) kódok: N73, O13

Kulcsszavak: EU-energiapolitika, energiaunió, villamosenergia-piac, ellátási felelôsség

\section{Summary}

Responsibility for the sustainable electricity supply cannot be left without serious attention when turning to a centralized European electricity market. European member

Dr. JÁrosi MárTon, elnök, Energiapolitika 2000 Társulat (drjarosi@enpol2000.hu), KovÁcs PÁL, a paksi kapacitásbôvítésért felelôs miniszter kabinetvezetôje (kovacsp@ mvmpaks2.hu). 


\section{Járosi Márton - Kovács Pál: Az energiaunió és a tagállami felelösség}

countries are facing different starting position in such a process. Smaller countries, smaller electricity markets may lose an important part of their energy mix, mainly the ones that are largely contributing to the electricity supply security. The same time a continuously increasing share of electricity imports opens completely unknown horizons to energy dependence from unreliable and distant energy sources inside Europe while the responsibility for electricity supply stands with the national governments. This process could also lead to concentration of market players endangering competition for small markets. Damages to electricity supply security after a certain range are unacceptable for some countries members to the European Union.

Journal of Economic Literature (JEL) codes: N73, O13

Keywords: energy policy in European Union, energy union, electricity market, supply responsibility

\section{BEVEZETÉS}

A nemzetek fennmaradásának egyik feltétele az állampolgárok életfeltételeinek és ezen belül az energiaellátásának a biztosítása. Az országot az általunk csak részben vagy szélsôségesebb esetben egyáltalán nem befolyásolható külsô körülmények között/ellenére is „üzemeltetni, múködtetni kell”; a felelôs kormánynak minden idóben biztosítani kell ennek egyik hajtóanyagát: az energiát. Az energetika azért vet fel súlyos társadalompolitikai kérdéseket, mert civilizációnk hajtóanyaga napjainkra az energiafogyasztás lett (Szergényi, 2015). Emellett a kontinensek közötti energetikai/infrastrukturális kapcsolatok és rendszerek a ma múködó szuperhatalmak közötti globális folyamatokat is befolyásolják.

Az EU már az alapszerzódésében is célul tûzte ki az energiapiacok múködésének egységes piaci alapokra helyezését és centralizált irányítását. A lisszaboni szerzôdésben foglaltakat a tagországok átültették a saját nemzeti jogrendjükbe. Ezzel a kormányok már deklaráltan feladták a nemzeti szuverenitásuk egy jelentôs és fontos részét, s ez az energetikára is kihat.

A „felelôsség” szó tartalma az energiaellátás szemszögébôl nézve elszánt törekvés a ránk bízottak energiaellátásáért, az ellentétes vagy eltérítô külsố hatások ellenére is. A cél, mind a lakosság, mind pedig az ipari fogyasztók részére, az energiaforrások és az energia biztosítása az igényelt helyszínen, az igényelt mennyiségben, az igényelt időpontban és időtartamban.

\section{Az EU ENERGIAPOLITIKAI CÉLKITƯZÉSEI}

Globális morális felelôsségünk, hogy megőrizzük az élhető környezetet az utánunk következô generációk számára. Ezzel viszont ellentétesen hat a kapitalista társadalmi berendezkedés. Alapvetô kérdés, hogy a környezeti beavatkozások minimalizálása és a 
kapitalista terjeszkedő, a termelést/fogyasztást/profitot maximalizáló folyamatok közötti konfliktus feloldható-e.

Egyrészt az EU már politikai szinten határozottan eldöntötte, hogy tenni fog a globális felmelegedés ellen, a zöldítés „bajnoka” lesz. Ezzel azonban Európa rövid és középtávon versenyhátrányba kerül más globális hatalmakkal szemben a megújuló energiaforrások technológiai fejlesztésének jelentôs frontend költségei, a szükséges hálózatfejlesztések és a már beépített berendezések rendkívül gyors elavulása (cseréjük szükségessége) miatt. Másrészt az európai zöldítés klímaváltozásra gyakorolt globális hatása önmagában elenyészô. A párizsi klímaegyezményból kihátráló USA várhatóan másokat is hasonló lépésekre ösztönöz majd - márpedig az EU egyedül nem képes befolyásolni a kibocsátásokat.

Az Európai Unió energiapolitikai célkitúzései elsôsorban gazdaságpolitikai természetúek. Ezt a megközelítést olvashatjuk ki az ún. Téli energiacsomagból ${ }^{1}$ is, amelyben kiemelten szerepelnek többek között az alábbiak:

- a fogyasztók korlátozás nélküli hozzáférése az energiához;

- a fogyasztók közvetlen bevonása az energiakereskedelembe;

- a DSO (Distribution System Operators, azaz elosztóhálózat-üzemeltetôk), TSO (Transmission System Operators, vagyis átvitelirendszer-üzemeltetôk) közös platformra és közös felügyelet alá helyezése $\left(\mathrm{ACER}^{2}\right)$;

- az árak liberalizálása;

- a szabad energiaszolgáltató-választás;

- az energiahatóságok múködésének egységesítése stb.

A felsorolásban szereplő gazdaságpolitikai célok egyikét sem lehet negatív jelzôvel illetni, mivel valójában mindegyik a fogyasztó érdekeit szolgálja. Ha azonban közelebbrôl górcsố alá vesszük az egyes tagországok eltérô gazdasági és társadalmi berendezkedését, erejét és érdekérvényesítô képességét, amely egyenesen arányos pl. a területével és lakosságának számosságával, akkor már más a kép. A következókben kiemelünk néhány lényeges vonást, amely önmagában is bemutatja, hogy miért szükséges az alapelvekkel vitatkozni.

A német-francia tengely globális versenyképessége határozza meg az EU piaci sikerét vagy bukását. Ezért a vezetô tagállamok érdekei mellé vagy felsorakoznak a kisebb gazdasági teljesítményú tagállamok, vagy lemaradnak, kirekesztôdnek. Amely tagállam ma nem áll a német gazdasági motor és a német-francia tengely mellé, és nem szolgálja annak céljait, az az EU globális piaci vesztét szolgálja - az EU szemszögéból valahogy így fogalmazódhat meg az átfogó piaci politika, iránymutatás.

A helyzet azonos az energiapiacon is. Az energetikai függetlenedés, az energiaimport, a káros energiaár-változásoknak való kitettség csökkentése az EU elemi érdeke, bár ez a küzdelem eddig látványosan eredménytelen, mivel az EU külsô kitettsége folyamatosan nôtt. A német „Energiewende” egy olyan mechanizmus, amely üzleti szempontból az állami ártámogatás mellett az egyéni befektetésekre épít, így a német állampolgárok számára a részvénypiac kedvezó hozamokkal szolgál, amíg a megcélzott termékek (napkollektorok, szélerômúvek) piaca dinamikusan bôvül. Amíg a piac bôvül, addig az importált energia és energiahordozók mértéke is csök- 


\section{Járosi Márton - Kovács Pál: Az energiaunió és a tagállami felelösség}

ken. A megújulós program finanszírozására azonban egyrészt csak a gazdagabb tagállamok képesek hosszabb távon, másrészt a gyártásból és foglalkoztatásból kimaradó országok saját belsố mérlegében az EU belsố piacáról történô technológia importja ugyancsak rontja a saját belsố kereskedelmi mérleget, és egy másik tagállam felé szipkázza ki a hazai tôkét. Egyelốre egy, az EU-n belül múködô pilótajátéknak vagyunk a szemtanúi és elszenvedôi, amely a kisebb tagállamok fogyasztói és adófizetố állampolgárai számára több szempontból is egyértelmúen káros. Ezt a fố mechanizmust kényszeríti ma az EU tagállamaira a németek által kitenyésztett „megújulós” energiapolitika.

A folyamatnak persze van még egypár ördögien zseniális következménye is:

- A gazdagabb tagállamok látszólag az egész EU energiafüggóségét csökkentik, és látszólag „nagyvonalúan” „olcsóbb” áramhoz juttatják a kevésbé tehetôsebb államokat. Ez egy határig pozitív folyamat, amíg az áram árának csökkentése az ellátás biztonságának sérülése nélkül folytatható.

- A folyamat mentén azonban látni kell, hogy a nemzetállamok saját energetikai képességei az olcsó (értsd: a gazdagabb, tehetôsebb tagállamok fizetôképesebb fogyasztói által támogatott) exportárammal leépülnek, piaci oldalról ellehetetlenülnek, idôvel megszúnnek múködni, és a függốség centralizált formája alakul ki a gazdagabb piacok/államok felôl a kevésbé tehetôs piacok, államok felé. ${ }^{3}$

- A megújuló áramot az EU piacain bárhol szabadon értékesítố cégek és nemzetek idôvel lassan „átveszik” (az ölükbe hull, tulajdont szereznek) az exportjukkal meghódított, az ellehetetlenülésig „leócsított” és kiszolgáltatott piacokat. Azaz egyfajta, az EU szintjén centralizált privatizációt hajtanak végre a saját javukra, más államok, fogyasztók és piacok kárára pusztán a piaci múködésen keresztül, „a fogyasztók védelme érdekében tesszük" jelszó égisze alatt.

Lássuk, hogy az EU tervezett energiapiaci szabályozási csomagja ebbe az irányba halad-e, vagy sem? E célból érdemes tanulmányozni Graham Weale, ${ }^{4}$ a bochumi Ruhr Egyetem Energia Gazdaságtan és Politika Tanszék professzorának elóadását, amely a Foratom közgyúlésén hangzott el Brüsszelben a 2016. év végén.

\section{A Téli cSOMAg KRITIKÁJA}

Graham Weale professzor szakmai véleménye a csomagról lehangoló. A szabályozási csomag elszakad a közgazdasági alapoktól, és általában összekeveri vagy szándékosan összemossa a piac és a verseny fogalmát. A professzor egyéni szakmai véleménye szerint hideg idôjárás esetén az európai villamosenergia-piac a jelenlegi állapotában nem kerülheti el a „blackout”-ot. ${ }^{5}$ Kifejtette, hogy a liberális piaci vízió és stratégia összeomlott. Szükséges egyfajta kapacitáselem beépítése az energetikai beruházások megtérülésének biztosítása érdekében. Ez önmagában még nem fenyegeti a piaci versenyt. A versenyt egyébként fenn kell tartani - mert hasznos -, de csak a helyes arányban/ mértékben. Meg kell szüntetni bármilyen piactorzító beavatkozást, támogatást, így pl. a megújuló energiaforrások állami támogatását. Az EU hosszú távú céljai így is elérhetốk, azokat nem szabad figyelmen kívül hagyni. 
Az energiapiacok szabályozása „a politikusok rémálma”, mivel a piac komplex jellegú:

- a villamos energia nem tárolható, de elfogadható áron kell értékesíteni;

- a megújuló energiaforrások terjedésével egyre nagyobb arányban szabályozhatatlan áram érkezik a piacra;

- extrém módon eltérô (közgazdasági értelemben is) technológiák közül kell kialakítani az energiakosarat;

- a termék közel 80\%-át a termelôk elôre értékesítik, egy nappal vagy néhány órával a megtermelése előtt.

A tárolhatóság hiányának köszönhetôen a rövid távú határköltség aránytalanul nagy hatással van a rendszer múködésére és a termék árára. Ez a tulajdonság egyetlen más szektorra sem jellemzô! A rövid távú határköltségre viszont a bankok nem adnak hitelt a túlzott megtérülési kockázat miatt, így a beruházások ellehetetlenülnek. A fogyasztóknak nincs befolyása sem a rövid, sem a hosszú távú határköltségek alakítására.

A piac múködési hiányosságának ékes bizonyítéka, hogy míg a nagykereskedôi piac 20-30 EUR/MWh szinten értékesít, és a nagyfogyasztók számára majdnem ezen a nyomott áron hozzáférhetô az áram, addig a kisfogyasztók aránytalanul magas áron, 140 EUR/MWh szinten vagy e fölött jutnak hozzá.

Ugyanakkor az áram árának struktúrájában két tényezô játszik szerepet: a verseny az elôre lekötött ár elnyerésében, amely megtérülést egyáltalán nem biztosít, illetve az azonnali piac „hiány”-ár spekulációja (amikor nem fúj a szél, és nem süt a nap; ekkor lehet magasabb árat érvényesíteni). Erre a mechanizmusra nem lehet piacot és fóként ellátásbiztonságot építeni. Itt nem képzôdik a beruházásokat ösztönzô piaci jelzés.

A problémákra megoldást adhatnak a hosszabb távra szóló kapacitáslekötési szerzôdések. Az energiapiacok felé a politikusok túl sok követelményt támasztanak. Ha egy politika eltávolodik a tiszta közgazdasági alapoktól, és ideológiai alapokra helyezi a piac múködését, akkor nagy hibát követ el, a piaca életképtelenné, szabályozhatatlanná válik, és akár össze is omolhat. Például a jelenlegi németországi politika a szélenergia esetében jól múködik, de ettôl még nem piacpolitika. A politikusi befolyás okozta hibák:

- Az energiapiaci szereplók nem határozhatják meg maguk, hogy milyen energiakosarat alakítsanak ki.

- A környezetvédelmi célkitúzések gyakran jóval szigorúbbak, mint amit a kibocsátás kereskedelmi rendszere piaci alapon indokolna.

- A szén- és atomerômúvek leállítása politikai indíttatású, nem piaci alapú; erôltetett és mesterséges;

- vagy éppen ellenkezóleg, a szükséges bezárásokkal szemben (pl. spanyol szénerómúvek) ellátásbiztonsági okokra hivatkoznak.

- A megújuló energiaforrásokra épülô technológiák finanszírozása eróltetett, miközben a piaci ösztönzôk teljes mértékben hiányoznak. (Ettôl függetlenül a legutóbbi szélerőmúárak 5,6 eurócent/kWh szinten mozogtak, és itt a németek nagy előszeretettel szokták megjegyezni, hogy mekkora áldozatokat hoztak az európai piacok érdekében, amikor milliárdokat költöttek a naperômúvek és szélerômúvek technológiájának 


\section{Járosi Márton - Kovács Pál: Az energiaunió és a tagállami felelösség}

tökéletesítésére [frontend költségek], amely a jelenlegi árakat egyáltalán lehetôvé tette. Kína versenyszorításáról nem esett szó. Mindenesetre bármilyen tíz ével ezelótti energiaár-prognózis hibás jövôképet alkotott napjaink energiapiacairól és piaci árairól; ami az európai piacokon az elmúlt évtizedben történt, azt senki sem látta előre!)

- A fogyasztói tarifák, amelyek az energiahatékonyságot kellene hogy szolgálják, veszélyeztetik a további villamosítást.

- Diszkrimináló adókat alkalmaznak.

- Fogyasztói csoportokat indokolatlanul védenek - emberi jogi kérdéseket kezelnek szociális piac formájában, durván beavatkozva az energiapiacok múködésébe.

Ma nem tudható, hogy a politikusok valóban a hiánypiaci múködés mellett akarnak-e maradni, vagy sem. Ez bizonytalanságot okoz a piaci szereplôkben, amelyek nem látják a saját „mozgásterüket”.

A Téli energiacsomag legnagyobb hibája, hogy a politikusok többségének az alapvetố tudása is hiányzik a klasszikus piacok múködésérôl:

- Nem tisztelik az energiapiacok egyedi sajátosságait és a piacra váró kihívásokat.

- Megalapozatlan és indokolatlan várakozásokat támasztanak az azonnali piacok lehetôségeivel és beruházásainak finanszírozásával szemben.

- Csak a nagykereskedói piacokra koncentrálnak.

- A végfelhasználó érdekeit teljesen figyelmen kívül hagyják a hosszú és a rövid távú árazási megoldásokban.

- Nem tudják korrekt módon megkülönböztetni és elválasztani az energiahatékonyságot az energiatakarékosságtól.

- Több szabályozási megoldást a legmagasabb szinten kezelnek, amelyeket inkább a $\mathrm{CO}_{2}$-kvóta kereskedelmi rendszerének feladatkörében kellene megoldani.

- Az amerikai (Kalifornia és New York-i sötét éjszakák) példa is igazolja, hogy hoszszú távon csak a fogyasztói szükségletek és a termelés egyensúlya önmagában nem határozza meg a piaci árakat (ehhez még a beruházási szükségleteket is hozzá kell adni, amire jelenleg nincs piaci mechanizmus).

A Téli csomag javaslatából hiányzik a szakmai következetesség.

\section{Az ACER véleménye}

Az ACER 2017. június 29-én tartotta legutóbbi közgyúlését Ljubljanában. Érdemes áttekinteni, mi is hangzott el a Téli csomaggal kapcsolatosan ezen a konferencián.

Sefcsovics energiaügyi biztos igyekezett a közös európai szabályozási, fejlesztési lépések elônyeit hangsúlyozni. A biztos meggyôzódése, hogy a klímaváltozás elleni küzdelem, a hatások elleni felkészülés ma az egyik „legjobb üzlet és befektetés”. A Bizottság minden EU-tagállam részére kötelezôen elôírta a nemzeti energia- és klímastratégia elkészítését. Eredményként értékelte a regionális irányítóközpontok megalakítását, a hálózathasználati szabályok megalkotását és a minimum jogi követelmények rendszerének meghatározását. Ezzel a Bizottság „betette a lábát az ajtóba”, a kormányok kezébôl lassan kicsúszik a döntési jogkör az energiakosár összetétele és az ellátás biztonságának biztosítása tekintetében. 
A Bizottság azzal is tisztában van, hogy a tagállamok szabályozó hatóságai tudatában vannak, hogy az irányítást elveszítik, ezért ellenérdekeltek a Bizottság által a Téli energiacsomag egy részében megfogalmazott célokkal szemben. Sefcsovics biztos szerint ez a konfliktus úgy hidalható át, hogy a nemzeti hálózati üzemeltetôktôl a valós idejú beavatkozás lehetôségét nem veszik el.

Összességében tehát az európai energiapiacokat felügyelô hivatal a Téli csomag elfogadását javasolja. Ezek alapján a Sefcsovics által óhajtott és felvázolt Európai Szolidaritásban való önkéntes és örömteli feloldódás eufóriája sokak számára a nemzeti önrendelkezés halálát fogja jelenteni. Teljesen természetes és megalapozott az EU keleti részén tapasztalható szkepticizmus.

\section{CEEP ${ }^{6}$-állásfoglalás a Téli energiacsomagról}

A CEEP energetikai lobbiszervezet 2017. május 4-i állásfoglalása ${ }^{7}$ alapján szintén úgy tapasztalja, hogy igen éles szakmai és politikai vita bontakozott ki a Téli csomag társadalmi vitája kapcsán, fôként az Unió keleti részén.

A csomag általános dicsérete mellett azonban kiemelik a tagországok közötti egyenlôtlen indulási feltételeket, ${ }^{8}$ konkrétan az Unió keleti részének az EU átlagos GDP-termeló képességéhez való felzárkóztatás szükségességét a program sikeres és támogatható végrehajtásához. Ezek után ismertetik a csomaggal (energiapiacok szabályozása, Energiapiaci direktíva javaslat, Megújuló direktíva javaslat) kapcsolatos kritikájukat.

- Megerôsítik a tagországok szuverén jogát a saját energiakosaruk formálásában.

- Szükségesnek tartják az energiaimport minimális szinten tartását, a hazai energiaforrások ellátás biztonságát erôsítố szerepét.

- Megerôsítik a technológiasemlegesség elvének hangsúlyozását, kiemelik az energiapiacokat torzító támogatások megszüntetésének fontosságát.

- Aláhúzzák, hogy az EU energiapolitikájának a tagországok szuverén energiapolitikáira kell épülnie, és nem fordítva.

- Hangsúlyozzák, hogy az energiaellátás biztonsága kiemelt kérdés. Szükségesnek tartják egy hazai energiaforrásokon alapuló minimum hazai beépített kapacitásszint meghatározását. Az ellátás biztonságának garantálásához a tagországok határkeresztezô kapacitásainak bôvítése önmagában nem megoldás.

- Erôsen kritizálják a határkeresztezô kapacitások külsố nagykereskedôk általi indokolatlan lekötését, amely a hazai termelők mozgásterét csökkenti, és teret ad a német hurokáramok ${ }^{9}$ piacot torzító betörésének.

- Külön foglalkoznak a német hurokáramok kritikájával. A jelenséget és annak piactorzító hatását rendkívül károsnak tartják, amellyel - sajnálatukra - a Téli energiacsomag érdemben nem foglalkozik, pedig nagyon is kellene. Az eltérô energetikai infrastruktúra következtében az EU keleti tagországait a hurokáramok kifejezetten károsan érintik, amely mellett az EU nem mehet el érdemi intézkedések nélkül.

- Kiállnak a kapacitáspiacok alkalmazása mellett, amely jelenleg is 11 tagországban sikeresen múködik, és amely kiváló eszköz az ellátás biztonságának garantálásában. 


\section{Járosi Márton - Kovács Pál: Az energiaunió és a tagállami felelösség}

- Kiállnak a megújuló energiaforrások teljesen piaci alapokon nyugvó integrációja mellett.

Amint az a fentiekból is látható, a Brüsszelben aktívan tevékenykedó lobbiszervezet véleménye megegyezik jelen tanulmány megállapításaival.

\section{A TAGÁLLAMOK ENERGETIKAI ÉRDEKEINEK ÉRVÉNYESÍTÉSI LEHETÓSÉGEI}

\section{A nagy hal megeszi a kis halat}

A nagy gazdasági/politikai befolyással bíró tagállamok érdeke az, hogy minden energiát, melyet elôállítanak, lehetôség szerint ók osszák el, ezzel automatikusan maguk alá gyúrik a gyenge gazdasági erôvel rendelkező tagországokat. Az utóbbiak a gazdasági erô mentén késóbb olyan kedvezótlen megállapodásokba is bele fognak menni (kénytelenek lesznek), melyek az országot egy negatív hurokba sodorják, és ebbôl nem tud kilépni, mert ahhoz már az egész rendszert kellene megváltoztatni. Nyilván ez utóbbi lehetetlen.

Például, ha elérik azt, hogy a fogyasztók számára az egyes energiakereskedók ott vásároljanak energiát, ahol akarnak - ez az uniós elvekkel teljesen szinkronban van, és a fogyasztó számára előnyös -, akkor a drágábban termelő kelet-közép-európai országok energiaszektorát teljesen tönkreteszik. Mindezt késôbb bagóért felvásárolják.

A nagyok elônye abban rejlik, hogy nekik volt idejük és pénzük felépíteni és modernizálni az energiaszektorukat, és most ezt a piaci előnyt érvényesíteni tudják, mivel mindenki ugyanabból a kútból iszik. Ma sem változott tehát a marxi gondolat, miszerint „a nagy hal megeszi a kis halat”; csak más eszközökkel teszik mindezt.

A kisebb európai tagállamok, köztük a kelet-európai tagországok, a kontinens piacainak újrafelosztásában vívott küzdelemben valójában nem támaszkodhatnak a saját gazdasági erejükre, ahogy érdemben nem számíthatnak politikai szövetségesekre sem. Az aktuális napi hírek alapján is látható, hogy a meghatározó EU-tagállamok mennyire erôs politikai nyomást fejtenek ki abban az esetben, ha valamelyik kisebb tagország ténylegesen „befeszül”. Van egy képletes magyar kifejezés, amely kiválóan leírja, hogy az EU meghatározó gazdasági hatalmai a kisebb tagországokkal mit is múvelnek: „leszalámiznak”. És hogy ezt miért is tehetik? A korlátok abból adódnak, hogy a keleti szektorban minden ország valós gazdasági hátrányból indult. A gazdaságilag erôs országok éppen ezért könnyen kijátsszák ôket egymás ellen. Ha szeretnének valamilyen múködô gazdasági formációt az ország számára kialkudni ebben az új rendben, akkor csak a tárgyalás és a jog eszközei maradnak. Egyetlen lehetôségük van érdekeik érvényesítésére - már amennyire ez lehetséges: az uniós jog mint eszköz. Megállapodni olyan megoldásokban, amelyeket az EU parlamentje elfogad, és jogszabályba is önt. Kizárólag ekkor van arra esély, hogy egy nagy tagországgal/magával az Unióval, érdeksérelem esetén, egy késôbbi fázisban tárgyalni lehessen. 


\section{Jogi lehetôségek és korlátok}

Az Európai Unió politikájának napjainkra vonatkozó alapvető dokumentuma a liszszaboni szerződés, mivel ez „szabályozza az Unió múködését, valamint megállapítja az Unió hatásköreinek területeit, elhatárolását és a hatáskörök gyakorlásának részletes szabályait”.

A lisszaboni szerzôdés célja, hogy megteremtse Európa népei között a mind szorosabb egység alapjait, hogy azok közös cselekvéssel biztosítsák államaik gazdasági és társadalmi fejlôdését; garantálják az egyenletes gazdasági növekedést, a kiegyensúlyozott kereskedelmet és a tisztességes piaci versenyt, törekedve arra, hogy erôsítsék gazdaságaik egységét, és biztosítsák harmonikus fejlődésüket a különböző régiók között meglévô különbségek és a hátrányos helyzetú régiók elmaradottságának csökkentésével. Nem a „megszüntetésével”, csak a „csökkentésével”, tehát nem cél a különbségek eltüntetése - így lesznek és maradnak továbbra is lemaradottak, vesztesek, és élősködhetnek tovább a gyốztesek. Érdemes itt elgondolkozni azon: ugyan miként is lehet harmonikusan fejlődni, ha a cél nem a különbségek eltüntetése?

A szerzôdésben meghatározott hatáskörök típusai:

- Kizárólagos hatáskör kizárólag az Unió alkothat és fogadhat el kötelezô erejú jogi aktust (belsố piaci versenyszabályok, így pl. a teljes energiapiac vagy nemzetközi megállapodás megkötése).

- Megosztott hatáskör: mind az Unió, mind pedig a tagállamok alkothatnak és elfogadhatnak kötelezó erejú jogi aktusokat. Azonban itt is az Unió gyakorlata az irányadó, azaz ha Brüsszel már szabályt alkotott, akkor a tagállamnak már nincs joga ugyanezen kérdés szabályozására, csak abban az esetben, ha errôl a jogáról Brüsszel esetleg hajlandó lenne lemondani.

Ez magyarán szólva annyit jelent, hogy „nincs rajtunk sapka”... Az Unió bármely területen alkothat a tagállam kormánya felett átnyúlva jogszabályt. Nemzeti szuverenitásunk tehát máris a porban tiporva hever... Lássuk ezt az energetika területén.

Az energiaügy területén az Unió és a tagállamok között megosztott hatáskörök alkalmazandók. A Tanács, a szerződésekben elôírt egyéb eljárások sérelme nélkül, a Bizottság javaslata alapján, a tagállamok közötti szolidaritás szellemében határozhat a gazdasági helyzetnek megfelelố intézkedésekrôl, különösen, ha egyes termékekkel való ellátásban - ideértve különösképpen az energia területét - súlyos nehézségek merülnek fel. Az Unió

- hozzájárul a transzeurópai hálózatok létrehozatalához és fejlesztéséhez az energiaipari infrastruktúra területén;

- iránymutatás-csomagot dolgoz ki, amely a transzeurópai hálózatok területén a tervezett intézkedések célkitúzéseire, prioritásaira és fốbb vonalaira vonatkozik; ezek az iránymutatások közös érdekú projekteket határoznak meg;

- végrehajt minden olyan intézkedést, különösen a múszaki szabványok összehangolásának területén, amely a hálózatok átjárhatóságának biztosításához szükséges;

- támogathatja - különösen megvalósíthatósági tanulmányok, hitelgaranciák vagy kamattámogatások formájában - a tagállamok által támogatott, közös érdekú projekteket; 


\section{Járosi Márton - Kovács Pál: Az energiaunió és a tagállami felelösség}

- a Tanács különleges jogalkotási eljárás keretében az Európai Parlamenttel, a Gazdasági és Szociális Bizottsággal és a Régiók Bizottságával folytatott konzultációt követôen, egyhangúan fogadja el a tagállamok valamelyikének különbözô energiaforrások közötti választását és energiaellátásának általános szerkezetét jelentôs mértékben érintô intézkedéseket.

Az Unió energiapolitikájának céljai - a tagállamok közötti szolidaritás szellemében a következók:

- az energiapiac múködésének biztosítása;

- az energiaellátás biztonságának garantálása az Unión belül;

- az energiahatékonyság és az energiatakarékosság, valamint az új és megújuló energiaforrások kifejlesztésének előmozdítása; és

- az energiahálózatok összekapcsolásának elômozdítása.

Ezek az intézkedések nem befolyásolhatják a tagállamok jogát az energiaforrások kiaknázására vonatkozó feltételek meghatározására, továbbá nem befolyásolhatják a tagállamok különbözô energiaforrások közötti választását és energiaellátásuk általános szerkezetét.

Megállapítható, hogy a lisszaboni szerzôdésbe foglalt jogi eszközök nem elégségesek a kisebb tagállamok energiapolitikai érdekeinek védelmére.

\section{NÉHÁNY UNIÓS ENERGETIKAI KÉRDÉS}

\section{A megújuló energiák}

Az Unió által erôltetett megújuló energiák felhasználása, a technológiák fejlesztése és alkalmazása csak csepp a tengerben. Ha a fogyasztást nem sikerül drasztikusan csökkenteni, akkor ennél sokkal hatékonyabb, nagyobb energiasúrúséget hordozó megoldást kell találni. A Francia Tudományos Akadémia energetikai bizottságának elemzése ${ }^{10}$ rámutat: a megújulókkal kapcsolatos „viták alapján az állampolgárok akár arra a téves következtetésre is juthatnak, hogy a megújuló energiaforrások tömeges fejlesztésének köszönhetôen az atomenergia és a fosszilis energiaforrások feleslegessé válnak, azoktól örökre meg lehetne szabadulni”.

A Nyugat civilizációja ma még jórészt a fosszilis energiaforrásokra épül, ezek a hajtóanyagai. Kimerülésük a civilizáció hanyatlását, megszúnését okozhatja. Ezáltal válik az energia civilizációnk egyik alapkérdésévé. Az energia helyzete, megítélése, jövoojének kérdései végigkísérik a civilizációnkat s annak jövőjét. Sajnos a nyugati civilizáció húzóereje pedig a végtelen növekedési igényú globális fogyasztás lett.

Globalizált világunkban már a fenntarthatóság értelmezése önmagában is megtévesztô: valójában a fogyasztás fenntarthatóságáról van szó, ami lehetetlen. A szükségletek alapvetôen a globális fogyasztói szemlélet eluralkodása miatt növekednek. Már a növekedés koncepciója is problematikus, lévén a Föld erőforrásai végesek. A globalitásnak a jelszava a növekedés, a fogyasztás. Az ún. „modern társadalom” és a már jól ismert kapitalizmus erre épül. Ezért globális küzdelem folyik a még meglévô természeti erőforrások birtoklásáért, de ezt különféle technikákkal, például a klímahisztériával 
álcázzák. Az energetika ezért vált stratégiai és napi politikai kérdéssé. Az energiaellátás létkérdései, a globális energetikai narratíva talaján, lokális szinten s így hazánkban is, az úgynevezett „ellenzék” köreiben is a „megélhetési napi politizálás” színvonalára süllyedtek. Így vált a hazai „ellenzék” a „zöld eszme” globális üzleti köreinek kiszolgálójává.

A globalizáció viszonyai között annak az országnak van túlélési esélye, amelynek elitje figyelembe veszi térsége komparatív gazdasági elônyeit-hátrányait, s amelyik ellent tud állni a globalizációs erôszaknak. Az „energetikai szakma” lehetôsége, hogy véleményével segítse a döntéshozókat. Örülhetünk annak, hogy 2014 óta a magyar politika hallgat a nemzeti elkötelezettségú energetikusokra. Hazánk már korábban felismerte a Francia Akadémia állásfoglalásában most megfogalmazott igazságokat, amit a Nemzeti Energiastratégia tartalmaz (NFM, 2012).

\section{Erôforráskérdések}

Aki ma kapacitást teremt, az évtizedekre szóló gazdasági, társadalmi, politikai stabilitást, más szóval biztonságot teremt. Az ellátás biztonságának garantálásához a jelenlegi torz versenypiac nem járul hozzá, tehát a felelôs kormányok beavatkozására, irányítására mindig is szükség volt/van/lesz. Ezt a jogot és az ellátásbiztonság szintje megítélésének és korrekciójának a jogát egyetlen nemzettől és annak kormányától sem lehet elvitatni. Az abszolút biztonságra csak törekedhetünk, de azt sosem érhetjük el, így a kormányok bármely javító intézkedése indokolt, ha a javítás ténye megállapítható. A biztonságra való törekvés viszont a társadalom teherbíró képességének a függvénye.

Az energiaszektor meglehetôsen tôkeintenzív szektor. A kereslet-kínálat és árak 20-30 évre elôrebecslése bizonytalan. Ezért a hosszú távú döntéseket csak közösségi/ kormányzati felelősséggel, a tényleges társadalmi szükségletek kielégítésének a szándékával, a szükséges cselekvés idôpontjában rendelkezésre álló információk alapján lehet és kell meghozni. Emiatt kényszerült Nagy-Britannia kormánya is, az atomerômú létesítése érdekében, évtizedekre elôre garanciát vállalni az áram árára. ${ }^{11}$

A kockázatot az ellátásért felelôs állam kénytelen vállalni, mivel az ellátásért felelôsséggel nem tartozó piaci szereplốk azt nem vállalják. Magyarország azért bôvíti az atomerômúvet, mert nincs más reális alternatíva az ország villamosenergia-ellátására (Enpol2000, 2017).

\section{Környezetvédelmi kérdések}

A világméretû közbeszédben, s így a párizsi konferencia propagandájában is, a világot meghatározó gazdasági-politikai erôk az éghajlatváltozást az „emberi tevékenység” következményének állították be, mintha az demokratikusan, konszenzussal elfogadott intézkedésekkel megváltoztatható lenne. Ezzel sikerült szétteríteni, személytelenné, megfoghatatlanná tenni a tôke felelôsségét az emberi társadalmat valóban fenyegető veszélyek kialakulásáért. Az emberi felelősségnek ez az értelmezése eltereli a figyelmet a valódi okokról. 


\section{Járosi Márton - Kovács Pál: Az energiaunió és a tagállami felelösség}

A nemzetek fennmaradásának egyik feltétele az állampolgárok életfeltételeinek, közte az energiaellátásának biztosítása.

Minden energiatermelés, vagyis energiaátalakítás visszafordíthatatlan, növeli az entrópiát, rombolja a környezetet. Az ember elhasználja, tönkreteszi a világot. Akár filozófiai, akár hitbeli megfontolásból, mindnyájunknak úgy kellene élni, hogy az egész világért is felelôsek vagyunk. Másrészrốl azonban elsôsorban a ránk bízott családunkért, kisebb közösségünkért, nemzetünkért vagyunk felelôsek: föl kell nevelni a gyermekeinket. Nem erkölcsös a globális tőke valós céljait leplező „környezetvédelem” ürügyén gyermekeink jövójére hivatkozni, akik, ha így megy tovább, meg sem születnek. A saját életüket szeretnék az emberek megélni, persze az utódaikra is gondolva. Az lenne erkölcsös, ha a nemzetek erôforrásaikkal arányosan segítenék elô a jó irányú változásokat, a „világproblémák” megoldását. Vagyis a gazdagoknak kellene példát mutatni, s nem a szegényebb országokat zsarolni (Járosi-Héjjas, 2015). A teljes régiókat ellátó központosított rendszerek és piacok kiépülése miatt egyre jobban elhalványul az egészséges félelem, kockázati érzék, amely az ellátás biztonsága iránti komfortérzet és végül a felelôsség eltolódásához vezet. Azok az országok, régiók, amelyek a közös megoldásokra támaszkodnak, egyre kiszolgáltatottabbakká válnak, és ezt csak késốn vagy egyáltalán észre sem fogják venni. ${ }^{12}$

\section{ÖSSZEFOGLALÁS}

A villamosenergia-szektorban az árak növekedése csak késôn jelzi a beruházás szükségességét. Amikor a beruházási döntéstôl számítva a következô erômú elindul, már jócskán kialakulnak részleges áramszünetek, korlátozások. Erre több példát is találunk az elmúlt időszak árampiaci történéseiben. Mindegyik esemény eltérô problémából indult, de ugyanaz lett a végeredménye: nagyobb régiókra gyorsan kiterjedô áramkimaradás.

Ez rávilágított arra a tényre, hogy amennyiben kézben akarjuk tartani az ellátásbiztonságot, és ez egyik vezérló elvünk, akkor léteznie kell egy független szakmai szervezetnek, amely évekkel elôre jelzi, hogy mikor kell elindítani egy erômú tervezését, építését és üzembe helyezését ahhoz, hogy a hasonló jelenségeket elkerüljük.

Nyilván nem mindegy, mit építünk (atom, szén, gáz, víz vagy megújuló), mindegyiknek eltérô a beruházásiidô-igénye, költsége és a teljesítménye. Fontos megemlíteni, hogy vannak feltételek is, ezek alapján egyáltalán nem biztos, hogy egy adott erômútípus megépíthetô-e, vagy sem. A korlátok egyben behatárolják a megoldási lehetôségeket is. Tehát a beruházásindukció megjelenését követôen még legalább 2-3 év az az idő, amit a lehetôségek kutatásával kell tölteni, majd elő kell teremteni az ehhez szükséges forrásokat is. Tapasztalatból mondhatjuk, hogy egy erômú megépítése - típusától függóen - a felmerülés és üzembe helyezés közötti idôt tekintve mintegy 7-10 év.

Sajnos az uniós Téli csomag tervezete alapján elmondható, hogy míg a megújulóenergia-technológiák elterjesztését az Unió beárazta, addig az ellátás biztonságának beárazása a mai napig nem történt meg. Kérdéses, hogy a német energiapolitika Eu- 
rópára történô erőltetése elviszi-e a tagországokat a falig, és jelentős és súlyos regionális ellátási problémákkal fogunk szembenézni, vagy a kijózanodás esetleg hátrányos gazdasági események nélkül lejátszódik.

Az ellátás biztonsága kezelésének hiánya súlyos hiba.

Következtetések:

- Nincs energiaunió, az ellátásbiztonságot/felelôsséget az uniós szabályozás nem garantálja, annak megteremtése/viselése tagállami hatáskör.

- Az uniós szabályozás gyakorlatilag csak a már megtermelt, beszerzett energia kereskedelmével, a szállító/elosztó infrastruktúra kérdéseivel foglalkozik.

- A rövid távú határköltségre alapozott piaci szabályozás nem biztosítja a szükségessé váló új kapacitások létrehozását.

- Új kapacitások gyakorlatilag csak tagállami garanciával létesülhetnek.

- A kisebb tagállamok energiapolitikai érdekei az EU-bürokrácia dzsungelében nehezen érvényesíthetôk, viszont a nagyok által korlátozhatók.

- Az uniós szabályozásnak nem célja az egyes régiók közötti különbségek kiegyenlítése, ezért a nagyok erőfölénye érvényesül.

- Az uniós jogi eszközök nem elégségesek a kisebb tagállamok érdekeinek védelmére.

- A környezetvédelmet a szénmentes/zöldenergia-termelésre egyszerúsítve, a megújulókat indokolatlanul felértékelik, kivonják a piaci szabályozás hatálya alól.

- A szén- és atomerômúvek leállítása politikai indíttatású, középtávon az energiaellátás biztonsága csak a fosszilis energiatermelés fenntartásával lehetséges.

- Az emberiség számára szükséges energiát - ha nem csökkenti a fogyasztását évezredes távlatban, a mai tudásunk szerint, csak az atomenergia tudja biztosítani. Az ehhez szükséges „nyersanyag” rendelkezésre áll.

\section{JEGYZETEK}

1 https://ec.europa.eu/energy/en/news/commission-proposes-new-rules-consumer-centred-cleanenergy-transition.

2 Agency for the Cooperation of Energy Regulators, avagy az Energiaszabályozók Együttmúködési Ügynöksége, www.acer.europa.eu/hu/Lapok/default.aspx. Az Ügynökséget a harmadik energiaügyi csomag hozta létre, hogy tovább segítse a villamos energia és a földgáz belsô energiapiacának megvalósítását. Az ACER hivatalosan 2011 márciusában kezdte meg múködését, a szlovéniai Ljubljanában található székhellyel. Az európai energiaszabályozók közötti együttmúködést támogató független európai struktúra révén biztosítja, hogy a piaci integráció és a szabályozási keretek harmonizálása az uniós energiapolitikai célkitûzések keretei között valósuljon meg. Ezek a célkitûzések az alábbiak megteremtését szolgálják: egy versenyképesebb, integrált piac, ahol a fogyasztóknak több választási lehetôsége van; egy hatékony energetikai infrastruktúra, amely garantálja az energia határokon átnyúló, szabad mozgását és az új energiaforrások szállítását, ezáltal növelve az ellátás biztonságát az uniós vállalkozások és fogyasztók számára; egy ellenôrzött, átlátható energiapiac, amely a fogyasztóknak garantálja a tisztességes, a költségeket tükrözô árakat, és megakadályozza a visszaéléseket. Az ACER tehát központi szerepet játszik az egységes energiapiac megteremtésében!

3 Az áramimport mértéke pl. Magyarország esetében éves átlagban 2016-ban már jóval meghaladta a 30\%-ot, az ára éppen a paksi atomerômú által termelt áram ára felett volt. Ez azt jelenti, hogy míg a magyar árampiacon a paksi áram szinte teljes mértékben elkel, addig pl. a lignit- vagy gázalapú ter- 


\section{Járosi Márton - Kovács Pál: Az energiaunió és a tagállami felelösség}

melésre berendezkedett erômúvek termelését az import korlátozza, egyúttal drágábbá is teszi, mert a kihasználtságuk is csökken. Így lassan a hazai erômúpark is tönkremegy, leépül, megszúnik. És valahol itt sérül az ellátás biztonsága és a nemzeti szuverenitás. Hasonló folyamatot tapasztalhattunk pl. a hazai cukorgyárak nyugat-európai piaci szereplốk által levezényelt tönkretétele kapcsán: 12 hazai gyárat tettek tönkre és szereltek le, és mióta elhalt a hazai cukoripar, azóta a cukor ára a háromszorosára növekedett, csak külföldi szállítótól szerezhetjük be a terméket. A mezôgazdaság részére okozott kárról nem is szólva. Csak a magyar ugarra van szükség...

4 Graham Weale angol származású professzor évtizedek óta Németországban él, angol létére ott is telepedett le. Elmondása szerint azért, mert „Németország Európa közepe és gazdasági motorja, így a legérdekesebb kutatási célterület a közgazdászok részére is”. Kutatási területe az energiapiacok átalakításának vizsgálata. Az RWE AG (a legnagyobb német energiaszolgáltató) igazgatóságának kilenc évig volt tagja. Dolgozott az ExxonMobil, a Deloitte cégeknél. Tagja az Európai Bizottság energiapiacok átalakításával kapcsolatos szakmai tanácsadó testületének, az Energy Transition Commissionnek (Energiapiacok Átalakítási Bizottsága). Gyakorlatilag közvetlenül szemlélte a Téli csomag fejlódését, így a szakmai véleményének kialakítására volt elegendố ideje és anyaga. Hosszabb ideje német állampolgárként pedig kifejezetten érdekes megismerni a német villamosenergia-piac és az Energiewende mûködésérôl kifejtett véleményét.

5 Blackout: Az országos hálózat teljes összeomlása, a hálózat legjelentôsebb üzemzavari eseménye, amelyre hazánkban már volt példa 1985 telén. Két nap kellett a hálózat felépítésére a téli hideg idôjárásban. Hasonló esemény volt Kaliforniában és a New Yorkban bekövetkezett sötét éjszakák idôszakában.

6 Central Europe Energy Partners, vagyis Közép-európai Energiapartnerség.

7 CEEP' Position Paper on the Regulation and the Directive on the internal market in electricity and the revision of the RES Directive.

8 „We highlight however that the rapid economic growth necessary to catch up with the EU's average GDP remains the priority for the most of Central European countries..."

9 A hurokáramok káros hatása már 2010 környékén érzékelhetôvé vált a V4-ek piacain. A jelenség lényege, hogy a Németország északi részein múködô szélerômúvekben termelt áram nem tud eljutni az országon belül a déli energiafogyasztó ipari régióba, csak a szomszédos országokon keresztül. Nincs és nem is tudnak létesíteni ilyen nagyfeszültségú átviteli gerincvezetéket Németországon belül. Ez azt jelenti, hogy Németország más országok hálózati kapacitását használja a saját céljaira. Viszont azt is jelenti, hogy amikor egy országnak szüksége lenne többlet-villamosenergiára, akkor ahhoz külföldi piacokról esetenként nem tud hozzájutni, mert a német áramok lefoglalják az átvitelre alkalmas és képes keresztmetszetet. A németek ezért a külsố „szolgáltatásért” semmilyen ellentételezésre nem hajlandóak, ami további vita tárgyát képezi az érintett nemzeti hatóságok s a piacot szabályozók között. A német hurokáramok a magyar árampiacon is mérhetố hatással voltak/vannak.

10 A Francia Tudományos Akadémia energetikai bizottságának 2017. április 19-ei elemzése. www.academiesciences.fr/pdf/rapport/lpdv_190417.pdf.

11 Az Unióban kettôs mérce érvényesül: a brüsszeli bürokrácia Cameronnal nem mert ujjat húzni. Az energiapolitikai diszkrimináció csak egyik megjelenési formája a kettôs mércének nevezett gyakorlatnak. Magyar nyelvünk szerint ez hamisságot jelent. A többi válságjelhez (kétsebességes EU, migránsválság) hasonlóan ez is az Unió széttöredezésének jele. A látszategység propagandája mögött egyre inkább az „egyenlôbbek” diktatúrája bontakozik ki, ami az EU végét jelentheti. A gyengébb tagállamok hosszú távú fennmaradását csak a nemzetállamok kormányainak felelôs politizálása biztosíthatja.

12 Belgium több alaperômú létesítésére alkalmas telephelye mára a francia EDF tulajdonába került, és a szomszédos Franciaországból komoly villamosenergia-importra szorulnak.

\section{FELHASZNÁLT IRODALOM}

Enpol2000 (2017): A paksi bỗvités egységes irányítást igényel. Az Energiapolitika 2000 Társulat állásfoglalása. http://enpol2000.hu/dokumentumok/allasfoglalasok/article/67-\%C3\%8111\%C3\%A1sfoglal\%C3\%A1sok\%20/610-a-paksi-bovites-megvalositasa-egyseges-iranyitastigenyel. 
Járosi Márton - Héjjas István (2015): Klímavédelem helyett ökológiai megtérés. Magyar Nemzet, 2015. július 20. www.enpol2000.hu/szakmai-keres/klimavedelem/article/Szakmai\%20keres\%C5\%91/30Kl\%C3\%ADmav\%C3\%A9delem/524-klimavedelem-helyett-okologiai-megteres.

NFM (2012): Nemzeti Energiastratégia 2030. Nemzeti Fejlesztési Minisztérium. http://2010-2014.kormany.hu/download/4/f8/70000/Nemzeti\%20Energiastrat\%C3\%A9gia\%202030\%20teljes\%20 v\%C3\%Alltozat.pdf.

Szergényi István (2015): Energia, civilizáció, szintézisigény. Typotex Kiadó, Budapest, 2015, www.enpol2000. $\mathrm{hu} /$ component/resource/article/3-Aktu\%C3\%A1lis/536-energia-civilizacio-szintezisigenykonyvbemutato. 